REFLEKSI HUKUM

Jurnal Ilmu Hukum
p-ISSN 2541-4984 | e-ISSN 2541-5417

Volume 4 Nomor 2, April 2020, Halaman 217-238

DOI: https://doi.org/10.24246/jrh.2020.v4.i2.p217-238

Open access at: http://ejournal.uksw.edu/refleksihukum

Penerbit: FakultasHukumUniversitas Kristen Satya Wacana

\title{
IMPLEMENTASI FUNGSI PENGAWASAN DEWAN PERWAKILAN RAKYAT DALAM UPAYA MEMPERKUAT SISTEM PRESIDENSIAL DI INDONESIA
}

\author{
Putu Eva Ditayani Antari \\ Fakultas Hukum Universitas Pendidikan Nasional \\ Korespodensi: evaditayaniantari@undiknas.ac.id
}

Naskah dikirim: 3 Januari 2020|Direvisi: 5 Februari 2020|Disetujui: 25 Juni 2020

\begin{abstract}
Abstrak
DPR memiliki fungsi pengawasan kepada kinerja Presiden disertai dengan hak mengusulkan pemberhentian Presiden kepada MPR, sebagai pelaksanaan fungsi pengawasan. Namun dalam sistem presidensial, hal ini bertentangan dengan syarat fixed term executive. Selain itu politisasi DPR dalam penggunaan hak tersebut menimbulkan anggapan bahwa fungsi pengawasan akan melemahkan sistem presidensial. Hal ini selanjutnya diteliti dan disajikan dalam penulisan analitik deskriptif, menggunakan metode penelitian hukum normatif. Berdasarkan analisis, fungsi pengawasan DPR dalam sistem presidensial tidak melemahkan sistem presidensial. Pengawasan merupakan perimbangan dan pengawasan terhadap kekuasaan Presiden. DPR sebagai lembaga pengawas harus taat pada asas transparansi, akuntabeL, independen dan imparsial. Selain itu adanya MK sebagai penentu keabsahan usul pemberhentian Presiden yang juga dapat mencegah politisasi dalam pemberhentian Presiden. Dengan demikian maka tercipta fungsi pengawasan DPR yang mampu mendukung jalannya sistem presidensial serta membentuk kekuasaan berimbang antar 3 (tiga) bidang kekuasaan negara menurut pandangan Montesquieu.
\end{abstract}

Kata-kata Kunci: Sistem Presidensial; Politisasi; Pengawasan.

\begin{abstract}
The House of Representatives of the Republic of Indonesia (DPR) has a supervisory function to the President's performance accompanied by the right to propose the dismissal of the President to the People's Consultative Assembly of the Republic of Indonesia (MPR), as the implementation of the oversight function. However, in a presidential system, this is contrary to the terms of the fixed term executive. Also, the politicization of the DPR in the use of these rights raises the perception that the oversight function will weaken the presidential system. This is further researched and presented in descriptive-analytic writing, using normative legal research method. Based on the analysis, the DPR's supervisory function in the presidential system does not weaken the presidential system. Supervision is a balance and supervision of the power of the President. DPR as a supervisory institution shall obey the principles of transparency, accountability, independence, and impartiality. In addition, the existence of the Constitutional Court as a determinant of the validity of the proposal to dismiss the President also can prevent politicization in the dismissal of the President. Thus the DPR's supervisory function was created which was able to support the running of the presidential system and establish a balanced power between 3 (three) fields of state power according to Montesquieu's perspective.
\end{abstract}

Keywords: Presidential System; Political Effort; Check 


\section{PENDAHULUAN}

Indonesia merupakan negara yang menerapkan sistem pemerintahan presidensial sejak awal kemerdekaannya, meskipun sempat pula menerapkan sistem parlementer saat menerapkan bentuk negara serikat (Republik Indonesia Serikat). Konsekuensi dari diterapkannya sistem presidensial dalam sistem pemerintahan Indonesia yaitu kekuasaan pemerintah dipegang penuh oleh Presiden yang memegang jabatan sebagai kepala negara dan kepala pemerintahannya, sesuai dengan ciri utama sistem pemerintahan presidensial. Dalam melaksanakan wewenangnya Presiden dibantu oleh seorang Wakil Presiden dan oleh menterimenteri yang telah dipilih oleh Presiden dalam suatu susunan kabinet.

Sistem pemerintahan presidensial atau yang sering pula disebut dengan sistem kongresial, yang dimana kekuasaan eksekutif dipilih melalui pemilu dan terpisah dengan kekuasaan legislatif sehingga lembaga legislatif dan lembaga eksekutif memiliki legitimasi jabatan yang sama karena merupakan hasil pemilihan langsung oleh rakyat. Masa jabatan Presiden dalam sistem pemerintahan presidensial juga telah ditetapkan secara pasti dan tidak dapat diberhentikan di tengah masa jabatannya. Meski demikian terdapat pengecualian bagi hal tersebut yaitu apabila Presiden melakukan hal-hal yang ditetapkan dalam konstitusi sebagai alasan-alasan pemberhentian Presiden dalam masa jabatannya. Pemberhetian Presiden dalam masa jabatannya disebut dengan pengecualian dari ciri fixed term executive.

Sistem pemerintahan presidensial yang memungkinkan adanya kekuasaan pemerintah yang terpusat pada Presiden, berpotensi untuk disalahgunakan apabila tanpa disertai adanya kewenangan berimbang yang dimiliki oleh bidang kekuasaan lainnya. Mencegah hal tersebut, maka Montesquieu menyampaikan pandangannya bahwa kekuasaan negara harus dipisahkan dan dibedakan secara struktural dalam organ-organ negara yang tidak saling mencampuri urusan organ negara satu dan lainnya. ${ }^{1}$ Teori Trias Politica yang dikemukakan oleh Montesquieu, membagi kekuasaan negara dalam 3 (tiga) kekuasaan, yaitu (1) kekuasaan legislatif atau kekuasaan membuat undang-undang (UU) (rule making function); (2) kekuasaan eksekutif atau kekuasaan melaksanakan UU (rule application function); (3) kekuasaan yudikatif atau kekuasaan mengadili atas pelanggaran UU (rule adjudication function).$^{2}$

Teori Trias Politica inilah yang diterapkan pula dalam sistem pemerintahan presidensial di Indonesia, dengan adanya pemisahan dan pembagian kekuasaan negara kepada masing-masing lembaga negara berdasarkan konstitusi. Pemisahan kekuasaan bersifat horizontal dalam arti kekuasaan dipisah-pisahkan ke dalam fungsi-fungsi yang tercermin dalam lembaga-lembaga negara yang sederajat dan saling mengimbangi (checks and balances). Sedangkan pembagian kekuasaan bersifat vertikal dalam arti perwujudan kekuasaan itu

Jimly Asshiddiqie, Pengantar Ilmu Hukum Tata Negara (RajaGrafindo 2006) 15.

John Pieris dan Aryanthi Baramuli Putri, Dewan Perwakilan Daerah Republik Indonesia, Studi, Analisis, Kritik, dan Solusi Kajian Hukum dan Politik (Pelangi Cendikia 2006) 29. 
dibagikan secara vertikal ke bawah kepada lembaga-lembaga tinggi negara di bawah lembaga pemegang kedaulatan rakyat. ${ }^{3}$

Adanya pemisahan dan pembagian kekuasaan dalam sistem pemerintahan Indonesia yang dipraktikkan di Indonesia, dalam pandangan Soepomo mempunyai sistem tersendiri. Soepomo menyatakan meskipun dalam pembagian kekuasaan itu setiap lembaga negara sudah mempunyai tugas tertentu, namun dimungkinkan adanya kerja sama antar lembaga negara satu dan lainnya. ${ }^{4}$ Pandangan berbeda disampaikan oleh Ismail Suny, yang menyatakan tidak penting dalam suatu negara hukum menganut Trias Politica atau tidak, melainkan adalah dapat atau tidaknya alat-alat kekuasaan itu terhindar dari praktik birokrasi dan tirani. Hal ini tidaklah tergantung pada pemisahan kekuasaan itu sendiri, tetapi kepada adanya sendi negara demokrasi yaitu kedaulatan rakyat. 5

Utrecht beranggapan teori pemisahan kekuasaan mengakibatkan adanya badan kenegaraan yang padanya tidak atau tidak dapat ditempatkan pengawasan badan kenegaraan lain, sehingga terbuka kemungkinan badan kenegaraan untuk bertindak melampaui kekuasaannya. Ditambahkannya lagi bahwa pembagian kekuasaan memang perlu namun tidak dibenarkan terjadinya pemisahan kekuasaan secara mutlak, sehingga menutup kemungkinan untuk saling melakukan pengawasan. ${ }^{6}$
Dengan demikian pola pemisahan kekuasaan ini sering pula disertai dengan implementasi check and balances antar bidang-bidang kekuasaan negara. Hal tersebut bertujuan agar lembaga-lembaga negara dalam melaksanakan wewenangnya dapat saling melakukan perimbangan dan pengawasan satu sama lain sehingga mencegah terjadinya monopoli-monopoli dalam satu bidang kekuasaan. Bahkan dalam sistem presidensial, Presiden yang memliki kedudukan sebagai kepala negara dan kepala pemerintahan pun tidak luput dari adanya pengawasan oleh lembaga negara lainnya.

Hal tersebut dapat dipahami dengan merujuk pada pandangan Kusnardi yang menyebutkan terkait dengan pelaksanaan pemisahan kekuasaan dalam negara, kekuasaan eksekutif harus dicegah jangan sampai kekuasaan itu melebihi daripada kekuasaan-kekuasaan yang lainnya, dengan membatasi kekuasaannya untuk tunduk kepada badan legislatif, misalnya dengan menetapkan parlemen sebagai badan pengawas terhadap pemerintah. Pelaksanaan pengawasan yang efektif terhadap pemerintah ialah dengan mengadakan pertanggungjawaban menteri. Dalam hal ini misalnya konstitusi negara Amerika Serikat, Presiden dalam beberapa hal dalam melaksanakan tugasnya diharuskan memperoleh persetujuan lebih lanjut dari

3 Jimly Asshidiqqie, Format Kelembagaan Negara dan Pergeseran Kekuasaan dalam UUD 1945 (FH UII Press 2004) 35.

Titik Triwulan Tutik, Konstruksi Hukum Tata Negara Indonesia Pasca Amandemen UUD 1945 (Kencana 2010) 75.

Ismail Suny, Pergeseran Kekuasaan Eksekutif (Aksara Baru 1986) 16.

Suwoto Mulyosudarmo, Peralihan Kekuasaan (Kajian Teoritis dan Yuridis terhadap Pidato Nawaksara) (Gramedia Pustaka Utama 1997) 28-29. 
senat. 7 Pendapat Kusnardi ini juga didukung dengan fakta terkini yang menunjukkan adanya upaya pemberhentian Donald Trump sebagai Presiden Amerika Serikat yang telah ditetapkan oleh House of Representative. Keputusan ini didasari oleh adanya dugaan bahwa Presiden Trump telah melakukan abuse of power dan mengancam keamanan intelijen Amerika Serikat. Meskipun pada tanggal 6 Februari 2020, Senat Amerika Serikat membebaskan Presiden Trump atas pemberhentian tersebut. ${ }^{8}$

Sebaliknya, Presiden juga dapat mengawasi kinerja dari lembaga legislatif suatu negara, sebagaimana yang diatur di Amerika Serikat dengan adanya kewenangan yang dimiliki oleh Presiden Amerika Serikat untuk menggunakan hak veto terkait UU yang ditetapkan oleh lembaga legislatifnya. Berbeda dengan mekanisme tersebut, proses pengawasan Presiden kepada lembaga legislatif di Indonesia dilaksanakan dengan kewenangan Presiden untuk turut serta dalam pelaksanaan kewenangan lembaga lainnya. Contohnya, dalam hal pembentukan UU di Indonesia merupakan kewenangan dari Dewan Perwakilan Rakyat (DPR), namun pelaksanaan kewenangan ini perlu disertai dengan adanya persetujuan bersama yang diberikan oleh Presiden, sebagaimana diatur dalam konstitusi.

Sebaliknya pengawasan yang dilakukan DPR terhadap Presiden dilakukan dengan adanya fungsi pengawasan yang dimiliki oleh anggota
DPR meliputi hak interpelasi, hak angket, dan hak menyatakan pendapat. Pengawasan akan dilaksanakan oleh DPR dalam hal terdapat kebijakan pemerintah yang dirasa janggal dan perlu untuk meminta keterangan atau penjelasan oleh pemerintah, atau perlu lebih lanjut dilakukan penyelidikan. Sebagaimana halnya di Amerika Serikat, pengawasan yang dilakukan oleh Presiden juga dapat berujung pada proses impeachment Presiden di Indonesia. Sehingga adanya fungsi pengawasan ini seolah mengecualikan ciri utama sistem pemerintahan presidensial yaitu fixed term executive.

Berdasarkan uraian yang dipaparkan di atas, maka dapat dirumuskan permasalahan sebagai berikut:

1. Bagaimana implementasi fungsi pengawasan DPR terhadap Presiden?

2. Apakah kewenangan DPR dalam melakukan pengawasan terhadap Presiden termasuk upaya memperkuat sistem pemerintahan presidensial?

Terhadap rumusan masalah tersebut, akan dilaksanakan penelitian hukum normatif (normative legal study) yaitu penelitian yang meneliti hukum dari perspektif internal dengan objek utama penelitiannya adalah norma hukum. ${ }^{9}$ Penelitian hukum normatif juga merupakan ciri khas dari penelitian ilmu hukum yang berfungsi dalam memberikan argumentasi yuridis ketika terjadi kekosongan, kekaburan, dan konflik

Kusnardi, Susunan Pembagian Kekuasaan menurut Sistem Undang-Undang Dasar 1945 (Gramedia 1986) 31-32.

BBC News, Trump Acquitted by Senate in Impeachment Trial (BBC News, 6 Februari 2020) <https://www.bbc.com/news/world-us-canada-51394383> diakses 10 Februari 2020.

I Made Pasek Diantha, Metodologi Penelitian Hukum Normatif dalam Justifikasi Teori Hukum (ed. revisi, Kencana 2017) 12. 
norma. ${ }^{10}$ Dalam melakukan penelitian ini menggunakan pendekatan perundang-undangan, historis, dan konseptual. Sehingga dalam penelitian ini dilakukan inventarisasi ketentuanketentuan mengenai penyelenggaraan sistem pemerintahan di Indonesia dan lembaga-lembaga negara yang diatur dalam peraturan perundang-undangan yang disandingkan dengan implementasi dari teori pemisahan kekuasaan yang disertai dengan prinsip check and balances. Selanjutnya dilaksanakan pula penelusuran sejarah amandemen Undang-Undang Dasar Negara Republik Indonsia Tahun 1945 (UUD NRI 1945) terutama mengenai perubahan pasal-pasal yang bertujuan memurnikan sistem pemerintahan presidensial.

Bahan hukum yang digunakan meliputi bahan hukum primer yaitu UUD NRI 1945 dan UU No. 17 Tahun 2014 tentang Majelis Permusyawaratan Rakyat, Dewan Perwakilan Rakyat, Dewan Perwakilan Daerah, dan Dewan Perwakilan Rakyat Daerah. Selain itu menggunakan pula bahan hukum sekunder yaitu berbagai buku, jurnal, dan karya ilmiah yang membahas mengenai pemisahan kekuasaan, sistem pemerintahan, fungsi-fungsi DPR, dan mekanisme check and balances. Seluruh bahan hukum tersebut dikumpulkan dengan mengadopsi teknik snowball dan dicatat dengan sistem kartu. Seluruh bahan hukum tersebut selanjutnya dianalisis dan dipaparkan guna mendapatkan kejelasan kesimpulan terkait rumusan masalah, sehingga penelitian ini termasuk penelitian deskriptif analisis.

\section{PEMBAHASAN}

\section{Konsepsi Pengawasan dalam Sistem Pemerintahan Indonesia}

Teori negara hukum sebagai konsep paling popular yang diterapkan dalam melandasi sistem pemerintahan suatu negara, mensyaratkan 3 (tiga) hal yaitu penerapan asas legalitas dalam pemerintahan, pemisahan kekuasaan negara, serta perlindungan terhadap Hak Asasi Manusia (HAM). Asas legalitas dalam penyelenggaraan pemerintahan dilaksanakan dengan memastikan bahwa setiap tindakan pemerintahan berdasarkan pada peraturan perundang-undangan yang berlaku. Dengan demikian maka kekuasaan pemerintah dapat dibatasi oleh perundang-undangan. Selanjutnya kekuasaan negara terbagi dengan merujuk pada Trias Politica, sebagai teori pemisahan kekuasaan paling popular yang diterapkan guna memisahkan kekuasaan negara dalam 3 (tiga) bidang yaitu legislatif, eksekutif, dan yudisial. Adanya pemisahan kekuasaan ini juga merupakan syarat dalam suatu negara hukum. Konsekuensi penerapan Trias Politica yaitu harus disertai dengan penerapan checks and balances guna mencegah monopoli kekuasaan negara dan tindakan kesewenang-wenangan penguasa. Terkait hal tersebut pula, maka perlindungan HAM menjadi hal substansial dalam negara hukum sehingga tidak terjadi tindak kesewenang-wenangan pemerintah kepada warga negaranya. Sehingga dapat disimpulkan bahwa inti utama dalam teori negara hukum adalah upaya untuk mencegah kesewenangwenangan pemerintah demi kesejah- 
teraan warga negara.

Trias Politica mengajarkan bahwa kekuasaan negara tidak dapat diletakkan pada satu lembaga saja, melainkan harus dipisahkan ke dalam tiga cabang kekuasaan yang disebut legislatif (membuat UU), eksekutif (menjalankan UU), dan yudisial (mengadili pelanggaran UU). Pandangan lainnya tentang Trias Politica juga dikemukakan oleh John Locke yang membagi menjadi kekuasaan legislatif (membuat UU), kekuasaan eksekutif (menjalankan UU), dan kekuasaan federatif (kekuasaan pemerintah dalam hubungan luar negeri).

Baik dalam pandangan Montesquieu maupun John Locke, bidangbidang kekuasaan yang telah terpisah tersebut selanjutnya diberikan kedudukan yang sederajat satu dan lainnya, dengan kewenangannya masingmasing yang bersifat atribusi. Meskipun menjalankan kewenangannya secara independen, namun masingmasing bidang kekuasaan tersebut tetap harus melaksanakan pengawasan dan perimbangan antara bidang kekuasaan yang satu dan lainnya.

Sistem pemerintahan Indonesia mengadopsi Trias Politica tersebut dengan membentuk lembaga-lembaga negara yang akan bertugas pada satu bidang kekuasaan. Dalam setiap bidang kekuasaan akan dijalankan oleh satu atau lebih lembaga negara lainnya. Sehingga keberadaan lembaga negara negara merupakan satu kesatuan yang tak terpisahkan dengan keberadaan negara. Keberadaan lembaga negara ini menjadi keniscayaan untuk mengisi dan menyelenggarakan negara. Pembentukan lembaga negara merupakan perwujudan dari mekanisme keterwakilan rakyat dalam menyelenggarakan pemerintahan. ${ }^{11}$ Maka secara definitif lembaga negara adalah institusi-institusi yang dibentuk guna melaksanakan fungsi-fungsi negara. ${ }^{12}$ Lebih lanjut Jimly Asshiddiqie menguraikan ciri-ciri lembaga negara yaitu: ${ }^{13}$

1) Organ negara itu dipilih atau diangkat untuk menduduki jabatan atau fungsi tertentu;

2) fungsi itu dijalankan sebagai profesi utama atau bahkan secara hukum bersifat eksklusif; dan

3) oleh karena fungsinya itu, ia berhak untuk mendapatkan imbalan gaji dari negara.

Lembaga-lembaga negara tersebut maka selanjutnya akan diklasifikasikan berdasarkan pada sumber peraturan yang menjadi dasar pembentukannya atau legitimasi lembaga tersebut, yaitu: ${ }^{14}$

1) Lembaga yang dibentuk berdasarkan UUD yang diatur dalam atau dengan UU, Peraturan Pemerintah (PP), Peraturan Presiden (Pepres), dan Keputusan Presiden (Kepres);

2) Lembaga yang dibentuk berdasarkan UU yang diatur dan ditentukan lebih lanjut dalam PP,

$11 \quad$ Firmansyah Arifin, dkk., Lembaga Negara dan Sengketa Kewenangan Antar Lembaga Negara (Konsorsium Reformasi Hukum Nasional (KRHN) 2005) 14.

12 Moh. Kusnardi dan Bintan Saragih, Imu Negara (ed. revisi, Gaya Media Pratama 2000) 241.

13 Dalam Anna Triningsih dan Nuzul Qur'aini Mardiya, 'Interpretasi Lembaga Negara dan Sengketa Lembaga Negara dalam Penyelesaian Sengketa Kewenangan Lembaga Negara' (2017) 14 (4) Jurnal Konstitusi 778, 786.

14 Asip Suyadi, 'Pembentukan dan Kewenangan Kantor Staf Kepresidenan (KSP) dalam Struktur Lembaga Kepresidenan Republik Indonesia' (2018) 9 (2) Jurnal Surya Kencana Satu: Dinamika Masalah Hukum dan Keadilan 91, 95. 
Perpres, dan Kepres;

3) Lembaga yang dibentuk berdasarkan PP atau Perpres yang ditentukan lebih lanjut Kepres;

4) Lembaga yang dibentuk berdasarkan Peraturan Menteri yang ditentukan lebih lanjut dengan Keputusan Menteri atau keputusan pejabat di bawah Menteri.

Selanjutnya lembaga-lembaga yang dibentuk UUD disebut sebagai lembaga negara utama yang tugas dan kewenangannya ditetapkan konstitusi menempati satu bidang kekuasaan dalam Trias Politica. Tafsiran Sri Soemantri menempatkan 8 (delapan) lembaga negara berdasarkan UUD NRI 1945 yaitu Badan Pemeriksa Keuangan (BPK), DPR, Dewan Perwakilan Daerah (DPD), Majelis Permusyawaratan Rakyat (MPR), Presiden dan Wakil Presiden, Mahkamah Agung (MA), Mahkamah Konstitusi, dan Komisi Yudisial. Pendapat ini didasarkan pemikiran sistem kelembagaan negara berdasarkan hasil amandemen UUD NRI 1945 dibagi menjadi 3 (tiga) bidang atau fungsi yaitu bidang perundang-undangan, bidang pengawasan, dan berkaitan dengan pengangkatan hakim agung. ${ }^{15}$

Adapun pembagian kekuasaan negara terhadap lembaga-lembaga negara dalam sistem pemerintahan Indonesia berdasarkan konstitusi dapat digambarkan dalam bagan sebagai berikut:
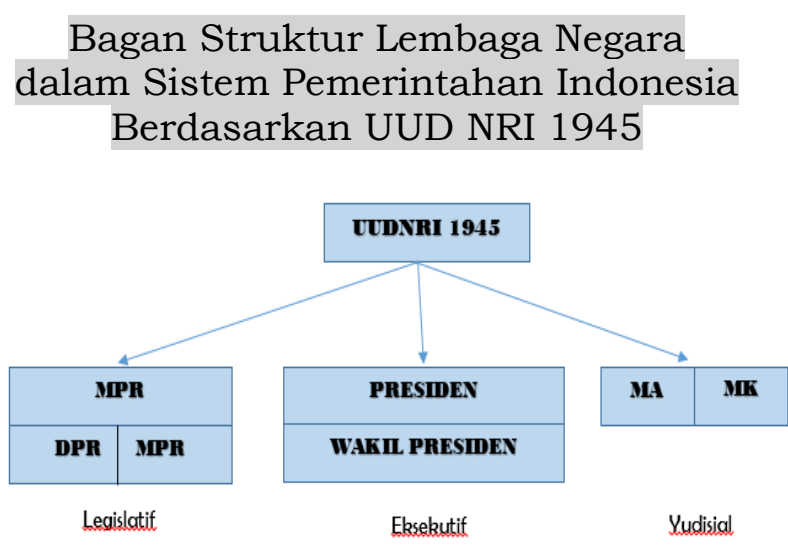

Masing-masing bidang kekuasaan tersebut akan melakukan pengawasan terhadap kinerja bidang kekuasaan lainnya. Sehingga akan tercipta hubungan yang bersifat reciprocal dalam hal pengawasan pada sistem pemerintahan di Indonesia. Presiden selaku eksekutif akan mengawasi kinerja DPR sebagai legislatif dalam pembentukan UU. Sebaliknya DPR akan mengawasi kinerja Presiden ketika menjalankan UU. Demikian pula antara MK sebagai kukuasaan yudikatif akan mengawasi DPR sebagai legislatif melalui pranata judicial review. Sementara DPR akan mengawasi MK dalam hal proses seleksi calon hakim MK yang dilakukan di DPR. Proses ini termasuk juga pengawasan antara kekuasaan yudikatif terhadap eksekutif dan sebaliknya.

Check and balances sebagai konsekuensi dari pemisahan kekuasaan negara bertujuan mencegah terjadinya monopoli satu bidang kekuasaan saja. Pengawasan dalam penyelenggaraan pemerintahan menurut Siagian merupakan segenap kegiatan untuk meyakinkan dan menjamin bahwa tugas/pekerjaan telah dilakukan sesuai dengan rencana yang telah 
ditetapkan. Kebijaksanaan yang telah digariskan dan perintah (aturan) yang diberikan. ${ }^{16}$ Sementara Kansil menambahkan bahwa pengawasan penting guna menjamin terlaksananya kebijakan pemerintah. ${ }^{17}$

Definisi lainnya mengenai pengawasan menurut Situmorang dan Jusuf Juhir merupakan setiap usaha dan tindakan dalam rangka untuk mengetahui sejauh mana pelaksanaan tugas yang melaksanakan menurut ketentuan dan sasaran yang hendak dicapai. ${ }^{18}$

Pengawasan tersebut ditinjau dari lembaga pelaksananya dapat dibedakan menjadi pengawasan internal dan pengawasan eksternal. Daly Erni menjabarkan pengawasan internal sebagai pengawasan yang dilakukan oleh orang dari badan/unit/ instansi di dalam lingkungan unit tersebut. Dilakukan dengan cara pengawasan atasan langsung atau pengawasan melekat. Sedangkan apabila pengawasan dilakukan oleh badan/unit/instansi yang berada di luar institusi yang diawasi disebut dengan pengawasan eksternal. ${ }^{19}$

Eza Aulia juga menambahkan bahwa pengawasan internal (internal control) dapat dicontohkan dengan keberadaan dewan etik/dewan kehormatan/majelis kehormatan dalam suatu lembaga yang memiliki kewenangan khusus untuk melakukan pengawasan terhadap etika, kinerja, dan perilaku dari lembaga atau orang per orangan yang diawasi. Sementara pengawasan eksternal (external control) biasanya dilakukan oleh suatu lembaga independen dan penilaiannya bersifat objektif. ${ }^{20}$

Berkaitan dengan kedua jenis pengawasan tersebut maka fungsi pengawasan yang dilaksanakan DPR terhadap Presiden digolongkan sebagai pengawasan eksternal. Sehingga pengawasan eksternal dapat di transformasikan dalam pelaksanaan check and balances antar lembaga karena memungkinkan lembaga lain mengawasi lembaga lainnya. Lembaga yang melakukan pengawasan tersebut dapat merupakan lembaga yang kewenangannya hanya melaksanakan pengawasan semata, seperti BPK. Selain itu pengawasan eksternal juga dapat dilakukan oleh lembaga lainnya manakala terdapat satu kewenangan yang dijalankan secara bersama-sama antara dua atau lebih bidang kekuasaan, contohnya keikutsertaan Presiden dalam pembentukan UU merupakan pengawasan eksekutif dalam proses pembentukan hukum. Selain itu terdapat pula lembaga yang menjalankan fungsi pengawasan sebagai salah satu kewenangannya bersama dengan kewenangan utamanya, seperti fungsi pengawasan DPR terhadap pemerintah meskipun kewenangan utamanya di bidang legislatif.

\section{Fungsi Pengawasan DPR}

DPR merupakan salah satu lembaga perwakilan rakyat di Indonesia, di samping MPR dan DPD sebagaimana ditetapkan dalam UUD NRI 1945 paska amandemen. Ketiga lembaga perwakilan rakyat tersebut

\footnotetext{
16 Sondang P. Siagian, Manajemen Sumber Daya Manusia (cet. 7, Bumi Aksara 2003) 112.

17 C.S.T. Kansil, Pemerintahan Daerah di Indonesia (Hukum Administrasi Daerah) (Sinar Grafika 2002) 1 .

18 Dalam Eza Aulia, 'Sistem Pengawasan terhadap Hakil Konstitusi dalam Mewujudkan Independensi Hakim' (2018) 2 (1) Jurnal Public Policy 105, 107.

19 Daly Erni, Pengawasan (Kencana 2008) 23.

20 Aulia, (n 18).
} 
menjalankan kewenangan berkaitan dengan bidang legislasi. Munif Rochmawanto mengutip pandangan Jimly Asshiddiqie menyatakan MPR bukanlah sebuat joint session (sidang gabungan) semata.21 Sebaliknya MPR merupakan sebuah lembaga yang keanggotaannya berasal dari anggota DPR dan DPD dengan kewenangan utama di bidang legislasi untuk mengubah dan menetapkan UUD.

DPR dan DPD sebagai lembaga pembentuk MPR merupakan lembaga perwakilan rakyat yang memiliki legitimasi kekuasaan berbeda. DPR merupakan lembaga perwakilan rakyat yang berasal dari partai politik, yang dipilih oleh rakyat melalui pemilu. Sementara DPD adalah lembaga yang baru terbentuk pasca amandemen UUD NRI 1945 sebagai pengganti dari fraksi utusan golongan dan utusan daerah. DPD merupakan lembaga perwakilan politik yang bersifat kedaerahan dan dicalonkan secara independen, tanpa memerlukan dukungan dari partai politik. Kedua lembaga tersebut memiliki fungsi legislasi dalam membentuk UU.

Keberadaan lembaga perwakilan rakyat tidak hanya berkaitan dengan fungsi legislasi, namun juga memiliki fungsi lainnya dalam rangka menjalankan kedaulatan rakyat dan demokrasi dalam suatu negara. DPR sebagai salah satu lembaga tersebut, memiliki 3 (tiga) fungsi yaitu (1) fungsi legislasi, (2) fungsi budgeting (penganggaran), dan (3) fungsi pengawasan. ${ }^{22}$ Pelaksanaan kewenangan DPR atas ketiga fungsi tersebut bukan merupakan produk amandemen UUD NRI 1945 melainkan telah ada sebelumnya yang dijabarkan sebagai berikut:

1) Fungsi legislatif, untuk membentuk memberikan persetujuan atas UU yang dibentuk Presiden (Pasal 20 ayat (1) UUD NRI 1945);

2) fungsi anggaran yaitu memberikan persetujuan atas anggaran pendapatan dan belanja yang diusulkan pemerintah (Pasal 23 ayat (1) UUD NRI 1945); dan

3) fungsi pengawasan dalam hal memberikan persetujuan kepada Presiden atas pernyataan perang, membuat perdamaian dan perjanjian dengan negara lain (Pasal 11 UUD NRI 1945).

Selain itu Bagir Manan menambahkan berdasarkan TAP MPR-RI No. III/MPR/1978, kewajiban DPR untuk senantiasa mengawasi tindakantindakan Presiden dalam rangka pelaksanaan haluan negara, apabila DPR menganggap bahwa Presiden sungguh melanggar haluan negara, maka DPR menyampaikan memorandum untuk mengingatkan Presiden. Apabila dalam waktu 3 bulan Presiden tidak memperhatikan memorandum DPR tersebut, maka DPR menyampaikan memorandum kedua. Apabila dalam waktu satu bulan memorandum kedua tersebut tidak diindahkan Presiden, maka DPR dapat meminta Majelis mengadakan sidang istimewa untuk meminta pertanggungjawaban Presiden. ${ }^{23}$

\footnotetext{
21 Munif Rochmawanto, 'Pembagian Kekuasaan antara MPR, DPR, dan DPD dalam Mewujudkan Sistem Ketatanegaraan yang Berkedaulatan Rakyat' (2014) 2 (1) Jurnal Independent 1.

22 Sunarto, 'Fungsi Legislasi DPR pasca Amandemen UUD 1945' (2017) 28 (1) Jurnal Integralistik 57.

23 Bagir Manan, Teori dan Politik Konstitusi, (Direktorat Jenderal Pendidikan Tinggi Departemen Pendidikan Nasional 2001) 134.
} 
Berdasarkan ketentuan pasal dalam UUD NRI 1945 dan penegasan Bagir Manan, maka kewenangan utama DPR merupakan kewenangan di bidang pengawasan. DPR sebagai lembaga legislatif nyatanya tidak diberikan kewenangan membentuk UU oleh konstitusi. Kewenangan DPR terkait legislasi hanya sebatas memberikan persetujuan atas UU yang dibentuk pemerintah. Selain itu dalam fungsi anggaran pun DPR hanya sebatas menyetujui atau tidak anggaran yang diajukan pemerintah. Hal ini pula yang menunjukkan adanya pemusatan kekuasaan negara pada Presiden sebelum amandemen UUD NRI 1945 yang disebut dengan executive heavy.

Fungsi legislasi yaitu fungsi DPR terkait dengan kewenangannya dalam hal membentuk UU. Selanjutnya fungsi budgeting (penganggaran), yaitu fungsi DPR terkait kewenangannya untuk ikut serta bersama pemerintah untuk menyusun Anggaran Pendapatan dan Belanja Negara (APBN). Terakhir, fungsi pengawasan, yaitu fungsi DPR dalam hal melakukan pengawasan terhadap kinerja pemerintah (Presiden) dalam menyelenggarakan pemerintahan.

Tiga fungsi yang dimiliki oleh DPR tersebut ditulis berurutan namun tidak berarti fungsi yang disebut terlebih dahulu lebih penting atau prioritas dibandingkan fungsi yang lainnya. Hanya saja pandangan umum seringkali menganggap fungsi legislasi sebagai fungsi utama dari lembaga perwakilan rakyat. Padahal dalam perkembangan terkini lembaga perwakilan rakyat di berbagai belahan dunia, fungsi pengawasan menjadi lebih utama dibandingkan lainnya. Hal ini mengingat adanya kelemahankelemahan yang harus dipenuhi untuk menyelenggarakan fungsi legislasi, yaitu:

1) Pengetahuan dan pemehaman para anggota DPR terhadap materi rancangan UU biasanya bersifat umum dan tidak mendetail karena latar belakang pendidikan anggotanya yang beragam;

2) DPR tidak didukung oleh tenaga ahli dalam jumlah yang cukup;

3) anggaran penyusunan rancangan UU yang terbatas; dan

4) proses pembahasan dan pengambilan putusan terhadap sebuah rancangan UU lebih rumit rumit dan lama, karena untuk memperoleh kesamaan pandangan harus melalui proses negosiasi, kompromi, serta lobi-lobi yang rumit dan lama.

Sebagaimana dikemukakan di atas bahwa kini fungsi pengawasan kini menjadi lebih utama dibandingkan fungsi-fungsi lainnya dibandingkan dengan fungsi legislasi ditinjau dari gagasan awal fungsi pembentukan lembaga perwakilan rakyat itu sendiri. Pengawasan yang dilaksanakan DPR terhadap Presiden merupakan pengawasan eksternal. Disebut demikian, mengingat keberadaan DPR dan Presiden pada bidang kekuasaan terpisah dalam Trias Politica. Penyelenggaraan fungsi pengawasan DPR apabila dicermati merupakan bentuk intervensi atau campur tangan lembaga legislatif terhadap lembaga eksekutif. Hal ini menunjukkan telah terjadinya pergeseran makna dari ajaran pemisahan kekuasaan, karena dalam ajaran tersebut ditekankan bahwa antar lembaga negara tidak boleh saling mengintervensi atau mencampuri urusan. Meskipun demikian, adanya campur tangan melalui fungsi pengawasan tersebut bertujuan 
untuk mengimbangi kekuasaan eksekutif yang seringkali mendapatkan godaan untuk bertindak di luar wewenangnya terutama dengan adanya wewenang diskresi yang dimiliki oleh eksekutif. Penggunaan wewenang diskresi ini yang dirasa perlu untuk diawasi legislatif karena berpotensi menimbulkan tidakan sewenangwenang dan penyalahgunaan wewenang.

Apabila implementasi check and balances dicermati dalam UUD NRI 1945, menunjukkan bahwa bukan hanya DPR yang memiliki fungsi pengawasan terhadap lembaga negara lainnya. Setiap lembaga negara akan dilibatkan untuk ikut serta melakukan pengawasan terhadap lembaga lainnya dalam bidang kekuasaan yang berbeda. Oleh karena itu mekanisme check and balances dalam UUD NRI 1945 sesungguhnya bersifat resiprok antara lembaga yang satu dengan lembaga lainnya. Urgensi implementasi check and balances demikian dapat dipahami dengan beranjak pada pandangan Lord Acton sebagaimana dikutip Miriam Budiardjo yang menyatakan bahwa power tends to corrupt, absolute power tends to corrupt absolutely (kekuasaan memiliki kecenderungan untuk disalahgunakan, tetapi kekuasaan yang absolut sudah pasti akan disalahgunakan). ${ }^{24}$ Sehingga dapat disimpulkan bahwa pengawasan merupakan syarat mutlak bagi kekuasaan agar tidak disalahgunakan, dan masing-masing lembaga negara memiliki fungsi untuk mengawasi lembaga lainnya guna tercapainya kekuasaan yang berimbang.

DPR mengawasi Presiden dengan cara menggunakan fungsi pengawas- annya terhadap setiap kebijakan yang diambil pemerintah dalam menyelenggarakan pemerintahan. Sebaliknya Presiden mengawasi dan mengimbangi kekuasaan DPR dengan cara diberikan kewenangan untuk turut serta membentuk UU. Keikutsertaan Presiden dalam pembentukan UU meliputi kewenangan untuk mengajukan RUU, ikut membahas rancangan UU bersama DPR, dan memberikan persetujuan untuk mengesahkan RUU sebagai UU.

Fungsi pengawasan DPR sebagai bentuk check and balances terhadap Presiden dalam kerangka pemisahan kekuasaan, dalam UU MD3 dilakukan terhadap pengawasan atas pelaksanaan UU dan APBN. Namun Jimly menyampaikan fungsi-fungsi pengawasan yang dimiliki oleh DPR sebagai lembaga perwakilan rakyat dapat dibedakan sebagai berikut:25

1) Pengawasan terhadap penentuan kebijakan (control of policy making);

2) pengawasan terhadap pelaksanaan kebijakan (control of policy executing);

3) pengawasan terhadap penganggaran dan belanja negara (control of budgeting);

4) pengawasan terhadap pelaksanaan anggaran dan belanja negara (control of budget implementation);

5) pengawasan terhadap kinerja pemerintahan (control of government performances); dan

6) pengawasan terhadap pengangkatan pejabat publik (control of political appointment of public officials) dalam bentuk persetujuan atau penolakan, ataupun

24 Miriam Budiardjo, Dasar-Dasar Ilmu Politik (ed. 6, Gramedia Pustaka Utama 2009) 52.
25 Asshiddiqie, Pengantar Imu Hukum Tata Negara (n 1) 302. 
dalam bentuk pemberian pertimbangan oleh DPR.

Fungsi pengawasan ini merupakan fungsi yang hadir pada hakikat atau asal usul lahirnya konsep parlemen sebagai lembaga perwakilan rakyat. Dalam sejarah kehadiran parlemen berkaitan dengan kata le parle yang berarti berbicara, artinya keberadaan wakil rakyat merupakan representasi dari rakyat yang menjadi juru bicara rakyat yaitu menyuarakan aspirasi, kepentingan, dan pendapat rakyat. Parlemen sebagai lembaga perwakilan rakyat merupakan wadah dimana kepentingan dan aspirasi rakyat diperdengarkan dan diperjuangkan untuk menjadi materi kebijakan dan agar kebijakan itu dilaksanakan dengan tepat untuk kepentingan seluruh rakyat yang aspirasinya diwakili. Dengan demikian fungsi pengawasan menurut Jimly lebih utama dibandingkan fungsi legislasi itu sendiri. Fungsi kontrol tidak saja berkenaan dengan kinerja pemerintah dalam melaksanakan ketentuan UU ataupun kebijakan yang telah ditentukan, melainkan berkaitan juga dengan penentuan anggaran dan pelaksanaan APBN yang telah ditetapkan. Dengan demikian maka dalam fungsi pengawasan sudah mencerminkan pula fungsi anggaran, yaitu pengawasan fiskal. 26

Fungsi pengawasan dilaksanakan oleh DPR sebagai lembaga perwakilan rakyat melalui hak-hak yang dimiliki oleh DPR sebagaimana termuat dalam Pasal 20A ayat (2) UUD NRI 1945 yaitu hak interpelasi, hak angket, dan hak menyatakan pendapat. ${ }^{27}$ Ketiga hak yang dimiliki oleh
DPR bertujuan untuk meminta keterangan kepada Presiden dalam hal terdapat kebijakannya yang dirasa salah, baik karena tindakan sewenang-wenang maupun penyalahgunaan wewenang. Ketiga hak DPR tersebut dipergunakan secara bertahap dimulai dari hak interpelasi, kemudian dilanjutkan hak angket, dan hak menyatakan pendapat sebagai hak yang dinilai sakral karena terkait dengan usulan pemberhentian Presiden dan/atau Wakil Presiden dalam masa jabatannya.

Adapun ketiga hak yang dimiliki oleh DPR dapat dijelaskan sebagaimana dikutip dari ketentuan Pasal 79 UU No. 17 Tahun 2014 tentang tentang Majelis Permusyawaratan Rakyat, Dewan Perwakilan Rakyat, Dewan Perwakilan Daerah, dan Dewan Perwakilan Rakyat Daerah sebagaimana yang telah diubah terakhir kali dengan UU No. 13 Tahun 2019 tentang Perubahan Ketiga atas UU No. 17 Tahun 2014 tentang Majelis Permusyawaratan Rakyat, Dewan Perwakilan Rakyat, Dewan Perwakilan Daerah, dan Dewan Perwakilan Rakyat Daerah, yaitu:

1) Hak interpelasi yaitu hak untuk meminta keterangan terhadap pemerintah mengenai kebijakan pemerintah yang penting dan strategis serta berdampak luas pada kehidupan bermasyarakat dan bernegara.

2) Hak angket adalah hak untuk melakukan penyelidikan yang dimiliki oleh DPR yang memutuskan bahwa pelaksanaan suatu UU dalam kebijakan pemerintah yang berkaitan dengan hal

\footnotetext{
26 Asshiddiqie, Pengantar Ilmu Hukum Tata Negara (n 1) 304.

27 May Lim Charity, 'Implikasi Hak Angket Dewak Perwakilan Rakyat Republik Indonesia terhadap Komisi Pemberantasan Korupsi' (2017) 14 (3) Jurnal Legislasi Indonesia 245, 247.
} 
penting, strategis, dan berdampak luas pada kehidupan bermasyarakat, berbangsa, dan bernegara bertentangan dengan ketentuan peraturan perundangundangan.

3) Hak menyatakan pendapat adalah hak DPR untuk menyatakan pendapat atas:

a) kebijakan pemerintah atau mengenai kejadian luar biasa yang terjadi di tanah air atau di dunia internasional;

b) tindak lanjut pelaksanaan hak interpelasi dan hak angket;

c) dugaan bahwa Presiden dan/atau Wakil Presiden tidak lagi memenuhi syarat sebagai Presiden dan/atau Wakil Presiden.

Penggunaan hak menyatakan pendapat itu dapat dikatakan sebagai fungsi pamungkas pengawasan DPR terhadap Presiden di Indonesia. Hal ini karena DPR dapat menggunakan hak tersebut untuk mengecualikan ciri fixed term executive yang telah diatur dalam konstitusi. Namun bukan berarti bahwa ketiga fungsi pengawasan tersebut bertujuan melemahkan sistem presidensial, apabila fungsi-fungsi tersebut dijalankan DPR secara bertanggung jawab dan tidak untuk kepentingan politik semata. DPR wajib bersikap obyektif dalam menggunakan fungsi-fungsi pengawasannya sebagai sarana kritik kebijakan pemerintah yang dirasa bertentangan dengan tujuan menyejahterakan masyarakat. Dengan demikian maka fungsi-fungsi pengawasan tersebut akan semakin memperkuat sistem presidensial dalam mencapai tujuan pemerintahan yang berorientasi pada rakyat, yang memberikan legitimasi kepada Presiden dan DPR.

\section{Fungsi Pengawasan DPR dalam Sistem Pemerintahan Presidensial}

Hubungan antara eksekutif, legislatif, dan yudisial dalam penyelenggaraan pemerintahan negara berkaitan erat dengan sistem pemerintahan yang dianut suatu negara. Hal ini dapat disimpulkan dari berbagai pandangan ahli hukum mengenai definisi sistem pemerintahan itu sendiri. Mahfud MD merumuskan definisi sistem pemerintahan sebagai mekanisme kerja dan koordinasi atau hubungan antara ketiga cabang kekuasaan yaitu legislatif, eksekutif dan yudikatif. ${ }^{28}$ Jimly Asshiddiqie juga mengemukakan bahwa sistem pemerintahan berkaitan dengan pengertian regeringsdaad, yaitu penyelenggaraan pemerintahan oleh eksekutif dalam hubungannya dengan fungsi legislatif. ${ }^{29}$ Selanjutnya pengertian sistem pemerintahan yang paling tegas dapat dilihat dari pendapat Usep Ranawijaya yang menyatakan sistem pemerintahan merupakan sistem hubungan antara eksekutif dan legislatif. 30 Dengan demikian menjadi amat jelas bahwa dalam setiap sistem pemerintahan yang ada, akan selalu terdapat keterkaitan kinerja antara eksekutif, legislatif, dan yudisial terkait dengan penyelenggaraan pemerintahan.

Sistem pemerintahan presidensial merupakan salah satu sistem pemerintahan yang diterapkan oleh

\footnotetext{
28 Moh. Mahfud M.D, Dasar dan Struktur Ketatanegaraan Indonesia (Rineka Cipta 2001) 74.

29 Jimly Asshiddiqie, Pokok-pokok Hukum Tata Negara Indonesia Pasca Reformasi (Ed. pertama, Buana Ilmu Populer 2007) 311.

$30 \quad$ Dalam Saldi Isra, 'Hubungan Presiden dan DPR' (2013) 10 (3) Jurnal Konstitusi 399, 403.
} 
negara-negara di dunia dengan berkiblat pada sistem presidensial yang diterapkan di Amerika Serikat. Meski demikian dalam implementasinya terdapat beberapa perkecualian yang dilakukan oleh negara-negara yang menerapkan sistem presidensial tersebut. Sistem presidensial memiliki ciri-ciri utama menurut Giovani Sartori sebagaimana dikutip oleh Hanta Yuda, yaitu: ${ }^{31}$

1) Kepala pemerintahan (presiden) dipilih secara langsung oleh rakyat untuk masa jabatan tertentu;

2) dalam masa jabatannya Presiden tidak dapat dijatuhkan oleh parlemen;

3) Presiden memimpin secara langsung pemerintahan yang dibentuknya.

Saldi Isra mengemukakan bahwa hampir semua ahli hukum yang mengemukakan pandangannya mengenai sistem pemerintahan presidensial menyatakan bahwa salah satu karakteristik sistem pemerintahan presidensial yang menonjol adalah Presiden memiliki fungsi ganda sebagai kepala negara dan kepala pemerintahan. ${ }^{32}$ Selanjutnya karakter sistem pemerintahan presidensial juga tampak dari pola hubungan antara lembaga eksekutif dan legislatif, dimana terdapat pemisahan secara tegas antara kedua lembaga tersebut (clear-cut separation of power). Dengan adanya pemisahan secara tegas tersebut, maka dalam sistem pemerintahan presidensial pembentukan pemerintah tidak tergantung pada proses politik di lembaga legislatif.
Namun legitimasi kedudukan Presiden sebagai kepala negara dan kepala pemerintahan dalam sistem presidensial akan tersandera oleh politik apabila penggunaan fungsi pengawasan oleh lembaga perwakilan rakyat sarat oleh upaya-upaya politik.

Sistem pemerintahan presidensial merupakan sistem pemerintahan yang menempatkan fokus kekuasaan terpusat pada lembaga eksekutif (Presiden). Dalam sistem pemerintahan presidensialisme, basis legitimasi Presiden bersumber dari rakyat dan karena itu sistem pemerintahan presidensial ditandai dengan penerapan sistem pemilihan Presiden dan Wakil Presiden secara langsung oleh rakyat dengan masa jabatan yang tetap (fixed term). Pemilihan Presiden dan Wakil Presiden secara langsung ini berimplikasi bahwa Presiden bertanggung jawab langsung kepada rakyat. Masa jabatan Presiden yang tetap bertujuan agar Presiden yang dipilih secara langsung oleh rakyat itu tidak mudah dijatuhkan oleh lembaga legislatif. Konsekuensinya adalah proses pemberhentian Presiden dan/atau wakil Presiden dari jabatannya hanya bisa dilakukan melalui proses peradilan. Selain itu, posisi lembaga eksekutif (Presiden dan Wakil Presiden) sejajar dengan posisi lembaga legislatif yang bertujuan agar kedua lembaga tersebut bersifat mandiri dan dapat melaksanakan mekanisme checks and balances dalam pemerintahan. ${ }^{33}$

Berdasarkan pandangan tentang sistem pemerintahan presidensial tersebut, maka implementasi sistem pemerintahan di Indonesia diwujud-

\footnotetext{
31 Hanta Yuda A.R., Presidensialisme Setengah Hati dari Dilema ke Kompromi (Gramedia Pustaka Utama 2010) 13.

32 Saldi Isra, Pergeseran Fungsi Legislasi Menguatnya Model Legislasi Parlementer dalam Sistem Presidensial Indonesia (PT. RajaGrafindo Persada 2010) 39-41.

$33 \quad$ A.R., (n 31) 10.
} 
kan dengan memposisikan jabatan Presiden sebagai kepala negara dan kepala pemerintahan (single chief executive). Selain itu, jabatan Presiden juga memiliki basis legitimasi kuat karena dipilih langsung oleh rakyat dalam masa jabatan yang tetap. Hal ini menimbulkan konsekuensi bahwa Presiden sebagai pemegang kekuasaan eksekutif bertanggung jawab langsung kepada rakyat, serta tidak dapat dengan mudah dijatuhkan oleh legislatif di tengah masa jabatannya karena pemerintahan tidak bergantung pada parlemen (lembaga legislatif) seperti pada sistem pemerintahan parlementer. Meski demikian hal itu tidak berarti bahwa Presiden tidak dapat diberhentikan dalam masa jabatannya, karena pemberhentian Presiden dapat dilaksanakan berdasarkan alasan-alasan yang dipandang sah dan sebelumnya telah ditentukan dalam konstitusi.

Sebagaimana telah disampaikan sebelumnya bahwa sejarah ketatanegaraan Indonesia menunjukkan ada 2 (dua) Presiden Indonesia yang diberhentikan dalam masa jabatannya melalui mekanisme impeachment yaitu Soekarno dan Abdurrahman Wahid (Gus Dur). Soekarno merupakan Presiden yang di-impeach berdasarkan TAP MPRS No. XXXIII/MPRS/1967 karena Soekarno dipandang tidak dapat melakukan kewajibannya dan tidak dapat melaksanakan haluan negara sebagaimana ditetapkan oleh UUD dan MPRS. ${ }^{34}$ Selain itu kuat dugaan pemberhentiannya disebabkan pula oleh keterlibatan Soekarno dalam G30S-PKI dan penunjukkannya sebagai Presiden seumur hidup yang jelas-jelas melanggar konstitusi Indonesia dan prinsip utama dalam sistem pemerintahan presidensial itu sendiri.

Berbeda dengan alasan pemberhentian Soekarno sebagai Presiden, lengsernya Abdurrahman Wahid sebagai Presiden Republik Indonesia ditetapkan dalam Sidang Istimewa MPR yang digelar pada Agustus 2001. Berdasarkan hasil keputusan sidang tersebut, maka MPR mencabut mandat atau memberhentikan Presiden Abdurrahman Wahid dengan alasan bahwa Presiden dinyatakan telah melanggar haluan negara, karena tidak hadir dan menolak untuk memberi pertanggungjawaban dalam Sidang Istimewa MPR, serta penerbitan Maklumat Presiden tanggal 23 Juli 2001 yang dianggap inkonstitusional oleh MPR. 35

Konflik politik antara Presiden dan DPR kala itu sesungguhnya menjadi awal mula proses impeachment terjadi, yang diawali adanya dugaan keterlibatan Abdurrahman Wahid dalam Buloggate dan Bruneigate. Saat Abdurrahman Wahid diminta keterangan oleh DPR, beliau malah melontarkan kritik terhadap keberadaan lembaga DPR itu sendiri. Hingga akhirnya adanya Maklumat Presiden tanggal 23 Juli 2001 yang berisi: 36
1) Membubarkan MPR dan DPR Republik Indonesia;
2) mengembalikan kedaulatan kepada rakyat dan membentuk

$34 \quad$ Fatkhurohman dan Miftachus Sjuhad, 'Memahami Pemberhentian Presiden (Impeachment) di Indonesia (Studi Perbandingan Pemberhentian Presiden Soekarno dan Presiden Abdurrahman Wahid' (2010) 3 (1) Jurnal Konstitusi 165, 168.

35 Abdul Rasyid Thalib, Wewenang Mahkamah Konstitusi dan Implikasinya dalam Sistem Ketatanegaraan Republik Indonesia (Citra Aditya Bakti 2006) 9.

36 Putu Eva Ditayani Antari, 'Penerapan Model Impeachment Dalam Pemberhentian Presiden dan/atau Wakil Presiden di Indonesia' (2016) 3 (1) Jurnal Hukum Undiknas 17, 24. 
Komisi Pemilihan Umum untuk mempersiapkan pemilu dalam waktu satu tahun; dan

3) menyelamatkan gerakan reformasi total dari fraksi Orde Baru dengan cara membubarkan Partai Golkar sementara menunggu keputusan MA.

Sehingga pemberhentian Abdurrahman Wahid dapat dikatakan memiliki intrik politik yang amat kentara antara Presiden dan DPR.

Proses pemberhentian Presiden dalam masa jabatannya yang sarat akan upaya politisasi DPR tidak hanya terjadi di Indonesia saja. Amerika Serikat sebagai negara kiblat sistem presidensial murni dengan demokrasinya pun tidak luput dari peristiwa pelemahan sistem presidensial tersebut. Setidaknya terdapat 4 (empat) orang dalam sejarah Amerika Serikat yang melalui proses impeachment yaitu Andrew Johnson, Richard Nixon, Bill Clinton, dan Donald Trump. ${ }^{37}$ Namun upaya impeachment terhadap Donald Trump merupakan proses yang menarik dilihat dilihat dari segala kontroversi yang timbul di Amerika Serikat sejak pemilihan hingga terkait segala kebijakan yang tidak populis yang diambil. Adanya konflik politik antara Presiden dengan kekuatan politik yang mendominasi House of Representative juga menjadi alasan utama mengapa Donald Trump dimakzulkan oleh House of Representative. Alasan pemberhentian Donald Trump yang didalilkan oleh House of Representative bahwa Donald Trump telah dengan sengaja melakukan intervensi kepada pemerintah Ukraina guna membantu pemenangannya dalam Pemilu AS 2020. Namun keputusan ini dianulir melalui persidangan impeachment yang dilaksanakan oleh Senate yang memutuskan bahwa alasan pemberhentian Donald Trump yang diajukan House of Representative tidak terbukti.

Peristiwa-peristiwa tersebut menunjukkan bahwa fungsi pengawasan terhadap Presiden yang dilakukan oleh DPR dapat melemahkan sistem presidensial, bila pelaksanaan fungsi tersebut berorientasi pada kepentingan politik semata. Mudahnya alasan dan mekanisme pemberhentian Presiden dalam 2 (dua) pemberhentian Presiden Indonesia tersebut juga menjadi salah satu concern dalam Perubahan UUD NRI 1945. Sebagaimana amanat 5 (lima) kesepakatan dasar perubahan UUD 1945, bahwa perubahan UUD NRI 1945 bertujuan untuk memperkuat sistem presidensial. Oleh karena itu, penyusun perubahan UUD NRI 1945 berusaha merumuskan alasan yang sah untuk memberhentikan Presiden sekaligus menyusun prosedur pemberhentian Presiden. Penyusun perubahan UUD NRI 1945 berkeinginan agar proses pemberhentian Presiden tidak hanya berdasarkan konflik politik, tanpa melalui proses investigasi dan pembuktian atas pelanggaran yang dilakukan Presiden. Atas dasar pertimbangan tersebut pasca amandemen dibentuklah MK yang salah satu kewenangannya untuk mengadili atau memberikan putusan atas pendapat DPR mengenai alasan-alasan pemberhentian Presiden dan/atau Wakil Presiden.

\footnotetext{
37 CNBC Indonesia, 'Trump Dimakzulkan! Ini Presiden AS Lain yang di-Impeachment' (CNBC, 19 Desember 2019) <https://www.cnbcindonesia.com/news/201912190 90738-4-124313/trumpdimakzulkan-ini-presiden-as-lain-yang-di-impeachment> diakses 10 Februari 2020.
} 
MK merupakan lembaga peradilan yang memiliki fungsi menyelenggarakan peradilan guna menegakkan konstitusi serta melakukan penafsiran terhadap konstitusi, termasuk dalam mekanisme pemberhentian Presiden dan/atau Wakil Presiden. Adanya kewenangan MK dalam proses pemberhentian Presiden dan/atau Wakil Presiden dalam pandangan Soimin dan Mahuriyanto bertujuan untuk melakukan perimbangan dan pengawasan terhadap mekanisme politik pemberhentian Presiden dan/ atau Wakil Presiden pada DPR dan MPR. Putusan MK merupakan dasar hukum yang kuat guna memberhentikan Presiden dan/atau Wakil Presiden, sesuai alasan-alasan yang diatur dalam UUD NRI 1945.38

Keterlibatan MK dalam menyelenggarakan peradilan pada proses pemberhentian Presiden dan/atau Wakil Presiden di Indonesia, bukan merupakan peralihan model impeachment ke model forum previlegiatum. Hal ini dinyatakan oleh Abdul Latif yang menyampaikan pandangannya disampaikan bahwa keterlibatan MK tidaklah mempengaruhi proses politik dalam pemberhentian Presiden dan/ atau Wakil Presiden. Putusan MK dalam pemberhentian Presiden dan/ atau wakil presiden tidaklah final dan dapat dianulir oleh keputusan MPR. 39 Pandangan serupa disampaikan pula oleh Ni'matul Huda yang menyatakan putusan MK tersebut bukan merupakan putusan final karena pemberhentian Presiden dan/atau Wakil Presiden tetap tunduk pada putusan
MPR sebagai lembaga politik yang berwenang. ${ }^{40}$

Kewenangan MK tersebut merupakan bentuk peran serta lembaga peradilan dalam proses pemberhentian Presiden dan/atau Wakil Presiden, yang bertujuan untuk mencegah upaya politisasi lembaga perwakilan rakyat dalam proses tersebut. Keputusan menyertakan lembaga peradilan merupakan pembelajaran dari sejarah pemberhentian Soekarno dan Abdurahman Wahid akibat kuatnya politisasi di DPR dan MPR. Kekuasaan Presiden yang dalam sistem presidensial amat kuat menjadi tersandera, karena adanya peluang untuk mempolitisasi alasan-alasan pemberhentian Presiden dan/atau Wakil Presiden. Terlebih lagi proses pemberhentiannya hanya dilakukan melalui mekanisme-mekanisme politik di DPR dan MPR.

Pasca amandemen UUD NRI 1945 mekanisme pemberhentian Presiden dan/atau Wakil Presiden dilakukan melalui tahapan peradilan dan politik, sebagaimana diatur dalam Pasal 7A dan 7B UUD NRI 1945 yang dapat pula dimaknai sebagai batasan bagi DPR dalam menjalankan fungsi pengawasan, khususnya penggunaan hak menyatakan pendapat. Alasan penggunaan hak menyatakan pendapat yang dapat menyebabkan pemberhentian Presiden menurut Pasal 7A UUD NRI 1945 yaitu apabila terbukti:

a) Melakukan pelanggaran hukum, berupa pengkhianatan terhadap negara, korupsi, penyuapan, tindak pidana berat lainnya, atau perbuatan tercela lainnya; atau

\footnotetext{
38 Soimin dan Mashuriyanto, Mahkamah Konstitusi dalam Sistem Ketatanegaraan Indonesia (UII Press 2013) 160.

39 Abdul Latif, Fungsi Mahkamah Konstitusi (Upaya Mewujudkan Negara Hukum Demokrasi) (Kreasi Total Media 2009) 164.

$40 \quad$ Ni'matul Huda, UUD 1945 dan Gagasan Amandemen Ulang (Rajawali Press 2008) 254.
} 
b) tidak lagi memenuhi syarat sebagai Presiden dan/atau Wakil Presiden.

Proses pembuktian dugaan tersebut selanjutnya diberikan kepada MK sebagaimana diatur Pasal 7B UUD NRI 1945 sehingga mekanisme impeachment memerlukan peran serta tiga lembaga yang berwenang yaitu DPR, MPR, dan MK. Tanpa adanya putusan MK yang menyatakan dugaan DPR untuk memberhentikan Presiden itu sah, maka hak menyatakan pendapat DPR tidak akan berlanjut dengan sidang impeachment di MPR. Sehingga proses pemberhentian Presiden berdasarkan UUD NRI 1945 dapat memperkecil celah DPR melakukan politisasi terhadap Presiden.

DPR dalam mekanisme pemberhentian Presiden dan/atau Wakil Presiden, berkaitan dengan fungsi pengawasan dan hak menyatakan pendapat, melakukan proses penyelidikan apabila ada dugaan pelanggaran hukum yang dilakukan oleh Presiden dan/atau Wakil Presiden. Penyelidikan yang dilakukan oleh DPR tidak dapat disamakan dengan proses penyelidikan, penyidikan, atau penuntutan yang dilakukan pada perkara pidana umumnya. Penyelidikan di DPR dilakukan dengan membentuk Panitia Khusus (Pansus) yang bertugas mencari bukti-bukti, meminta keterangan saksi dan pihak-pihak terkait termasuk membicarakannya dengan Presiden dalam suatu Rapat Kerja, Rapat Dengar Pendapat, dan/atau Rapat Dengar Pendapat Umum. ${ }^{41}$

Bagaimanapun DPR merupakan lembaga politik sehingga pengambilan keputusan yang dilakukan berkaitan dengan pemberhentian Presiden dan/ atau Wakil Presiden merupakan keputusan politik pula yang amat bergantung pada pandangan subyektif dan dukungan terhadap Presiden dan/atau Wakil Presiden. Oleh karena itulah maka diperlukan peran serta MK sebagai lembaga yudisial yang berwenang memutus kebenaran dugaan DPR bahwa Presiden dan/atau Wakil Presiden melakukan pelanggaran hukum atau tidak lagi memenuhi syarat sebagai Presiden dan/atau Wakil Presiden. Putusan yang diambil oleh MK tersebut diambil dalam perspektif hukum, sehingga dugaan DPR bahwa Presiden dan/Wakil Presiden telah melakukan pelanggaran hukum atau tidak lagi memenuhi syarat sebagai Presiden dan/atau Wakil Presiden yang sifatnya politik akan mendapatkan justifikasi secara hukum kebenarannya. Sehingga pendapat DPR yang bersifat politis mengenai alasan pemberhentian Presiden dan/atau Wakil Presiden itu dapat dipertanggungjawabkan secara hukum. Dengan demikian maka Presiden dan/atau Wakil Presiden tidak dapat dengan mudah diberhentikan dalam masa jabatannya berdasarkan mekanisme politik semata di DPR dan MPR, sehingga dapat menjamin kestabilan pemerintahan negara dalam sistem pemerintahan presidensial.

Usulan DPR mengenai dugaan Presiden dan/Wakil Presiden telah melakukan pelanggaran hukum atau tidak lagi memenuhi syarat sebagai Presiden dan/atau Wakil Presiden yang telah mendapat justifikasi hukum melalui putusan MK selanjutnya akan diteruskan oleh DPR ke MPR sebagai lembaga yang memiliki kewenangan konstitusional untuk

$41 \quad$ Hamdan Zoelva, Pemakzulan Presiden di Indonesia (Sinar Grafika 2011) 121. 
memberhentikan Presiden dan/atau Wakil Presiden. MPR akan menyelenggarakan Rapat Paripurna yang dihadiri oleh anggota MPR serta mengundang pula Presiden dan/atau Wakil Presiden guna memberikan penjelasan atas usul pemberhentiannya. Presiden dan/atau Wakil Presiden dapat menghadiri Rapat Paripurna MPR ataupun tidak. Dalam Rapat Paripurna tersebut pula diambil keputusan MPR melalui pengambilan suara terbanyak yang akan menentukan pemberhentian Presiden dan/atau Wakil Presiden dilaksanakan atau tidak. Pengambilan keputusan MPR melalui suara terbanyak tersebut merupakan proses politik, yang bisa saja tidak sesuai dengan kepastian hukum yang telah ditentukan melalui putusan MK sebelumnya. Meski demikian setidaknya wewenang MK tersebut telah memberikan filter sebagai bentuk upaya pencegahan upaya politisasi dalam pemberhentian Presiden dan/atau Wakil Presiden, yang dapat melemahkan sistem presidensial Indonesia.

\section{PENUTUP}

Implementasi fungsi pengawasannya DPR terhadap Presiden dilaksanakan dengan pengawasan atas pelaksanaan UU dan APBN. Fungsi pengawasan tersebut dijalankan dengan adanya 3 (tiga) hak DPR yaitu hak interpelasi, hak angket, dan hak menyatakan pendapat. Ketiga hak tersebut bertujuan meminta keterangan dari pemerintah (Presiden) dalam hal terdapat kebijakan pemerintah yang merugikan kepentingan umum.

Fungsi pengawasan DPR terhadap Presiden yang dapat mengakibatkan pemberhentian Presiden dalam masa jabatannya tidak akan mele- mahkan sistem presidensial. Sebaliknya adanya pengawasan tersebut semata sebagai bentuk perimbangan dan pengawasan terhadap kekuasaan Presiden yang besar, sehingga menghindarkan timbulnya tindakan sewenang-wenang. Dengan demikian maka fungsi pengawasan DPR terhadap Presiden memperkuat sistem presidensial, dengan menjamin bahwa dalam sistem presidensial akan menjamin stabilitas pemerintahan dan segala kebijakan yang ditetapkan pemerintah berorientasi pada rakyat selaku sumber legitimasi kekuasaannya.

DPR sebagai lembaga yang sarat akan kepentingan politis dalam menjalankan fungsi pengawasannya harus jauh dari unsur politik, semisal dengan maksud mempertahankan kekuasaan dan demi kepentingan kelompoknya semata. Jangan sampai fungsi pengawasan tersebut menjadi boomerang bagi sistem presidensial, karena justru akan melemahkan kedudukan Presiden itu sendiri. Fungsi pengawasan DPR harusnya merupakan sarana preventif dari kesewenang-wenangan Presiden. Oleh karenanya sifat pengawasan tersebut harus transparan, akuntabel, independen dan imparsial (tidak berkaitan dengan posisi sebagai kelompok pro atau oposisi dalam pemerintahan). Selain itu adanya kewajiban MK mengadili keabsahan alasan pemberhentian Presiden dan/atau Wakil Presiden di Indonesia saat ini juga dirasa cukup untuk mencegah terjadinya intrik politik antara DPR dan Presiden yang berujung pada impeachment. Upaya tersebut sekiranya dapat menciptakan fungsi pengawasan DPR yang mampu mendukung jalannya sistem presidensial. Pengawasan menjamin orientasi 
penyelenggaraan pemerintahan kepada rakyat sebagai sumber legitimasi jabatan Presiden. Pengawasan tersebut juga menjamin bahwa Presiden yang berkedudukan sebaga kepala negara dan kepala pemerintahan, tidak akan menyalahgunakan kekuasaan yang dominan ada padanya (executive heavy) untuk disalahgunakan. Dengan demikian maka tujuan utama sistem presidensial yaitu stabilitas pemerintahan dapat terwujud.

\section{DAFTAR BACAAN}

\section{Buku}

Arifin F, dkk., Lembaga Negara dan Sengketa Kewenangan Antar Lembaga Negara (Konsorsium Reformasi Hukum Nasional (KRHN) 2005).

Asshidiqqie J, Format Kelembagaan Negara dan Pergeseran Kekuasaan dalam UUD 1945 (FH UII Press 2004).

---------------, Pengantar Ilmu Hukum Tata Negara (RajaGrafindo 2006). , Pokok-pokok Hukum Tata Negara Indonesia Pasca Reformasi (Buana Ilmu Populer 2007).

Budiardjo M, Dasar-Dasar Ilmu Politik (ed. 6, Gramedia Pustaka Utama 2009).

D Mahfud M, Dasar dan Struktur Ketatanegaraan Indonesia (Rineka Cipta 2001).

Diantha IMP, Metodologi Penelitian Hukum Normatif dalam Justifikasi Teori Hukum (ed. revisi, Kencana 2017).

Erni D, Pengawasan (Kencana 2008).
Huda N, UUD 1945 dan Gagasan Amandemen Ulang (Rajawali Press 2008).

Isra S, Pergeseran Fungsi Legislasi Menguatnya Model Legislasi Parlementer dalam Sistem Presidensial Indonesia (PT. RajaGrafindo Persada 2010).

Kansil CST, Pemerintahan Daerah di Indonesia (Hukum Administrasi Daerah) (Sinar Grafika 2002).

Kusnardi M, Susunan Pembagian Kekuasaan menurut Sistem Undang-Undang Dasar 1945 (Gramedia 1986).

Kusnardi M dan Saragih B, Ilmu Negara (ed. revisi, Gaya Media Pratama 2000).

Latif A, Fungsi Mahkamah Konstitusi (Upaya Mewujudkan Negara Hukum Demokrasi) (Kreasi Total Media 2009).

Manan B, Teori dan Politik Konstitusi (Direktorat Jenderal Pendidikan Tinggi Departemen Pendidikan Nasional 2001).

Mulyosudarmo S, Peralihan Kekuasaan (Kajian Teoritis dan Yuridis terhadap Pidato Nawaksara) (Gramedia Pustaka Utama 1997).

Pieris J dan Putri AB, Dewan Perwakilan Daerah Republik Indonesia, Studi, Analisis, Kritik, dan Solusi Kajian Hukum dan Politik (Pelangi Cendikia 2006).

R Hanta YA, Presidensialisme Setengah Hati dari Dilema ke Kompromi (Gramedia Pustaka Utama 2010).

Siagian SP, Manajemen Sumber Daya Manusia (cet. 7, Bumi Aksara 2003). 
Soimin dan Mashuriyanto, Mahkamah Konstitusi dalam Sistem Ketatanegaraan Indonesia (UII Press 2013).

Suny I, Pergeseran Kekuasaan Eksekutif (Aksara Baru 1986).

Thalib AR, Wewenang Mahkamah Konstitusi dan Implikasinya dalam Sistem Ketatanegaraan Republik Indonesia (Citra Aditya Bakti 2006).

Tutik TT, Konstruksi Hukum Tata Negara Indonesia Pasca Amandemen UUD 1945 (Kencana 2010).

Zoelva H, Pemakzulan Presiden di Indonesia (Sinar Grafika 2011).

\section{Artikel Jurnal}

Antari PED, 'Penerapan Model Impeachment Dalam Pemberhentian Presiden dan/atau Wakil Presiden di Indonesia' (2016) 3 (1) Jurnal Hukum Undiknas.

Aulia E, 'Sistem Pengawasan terhadap Hakil Konstitusi dalam Mewujudkan Independensi Hakim' (2018) 2 (1) Jurnal Public Policy.

Charity ML, 'Implikasi Hak Angket Dewak Perwakilan Rakyat Republik Indonesia terhadap Komisi Pemberantasan Korupsi' (2017) 14 (3) Jurnal Legislasi Indonesia.

Fatkhurohman dan Sjuhad M, 'Memahami Pemberhentian Presiden (Impeachment) di Indonesia (Studi Perbandingan Pemberhentian Presiden Soekarno dan Presiden Abdurrahman Wahid' (2010) 3 (1) Jurnal Konstitusi.

Isra S, 'Hubungan Presiden dan DPR' (2013) 10 (3) Jurnal Konstitusi.
Rochmawanto M, 'Pembagian Kekuasaan antara MPR, DPR, dan DPD dalam Mewujudkan Sistem Ketatanegaraan yang Berkedaulatan Rakyat' (2014) 2 (1) Jurnal Independent.

Sunarto, 'Fungsi Legislasi DPR Pasca Amandemen UUD 1945' (2015) (28) (1) Jurnal Integralistik.

Suyadi A, 'Pembentukan dan Kewenangan Kantor Staf Kepresidenan (KSP) dalam Struktur Lembaga Kepresidenan Republik Indonesia' (2018) 10 (2) Jurnal Surya Kencana Satu: Dinamika Masalah Hukum dan Keadilan.

Triningsih A dan Mardiya NQ, 'Interpretasi Lembaga Negara dan Sengketa Lembaga Negara dalam Penyelesaian Sengketa Kewenangan Lembaga Negara' (2017) 14 (4) Jurnal Konstitusi.

\section{Artikel Koran}

BBC News, 'Trump Acquitted by Senate in Impeachment Trial' (BBC News, 6 Februari 2020) <https:// www.bbc.com/news/world-us-can ada-51394383> diakses 10 Februari 2020.

CNBC Indonesia, 'Trump Dimakzulkan! Ini Presiden AS Lain yang diImpeachment' (CNBC, 19 Desember 2019) <https://www. cnbcindonesia.com/news/20191 219090738-4-124313/trump-di makzulkan-ini-presiden-as-lainyang-di-impeachment> diakses 10 Februari 2020.

\section{Peraturan Perundang-Undangan}

Undang-Undang Dasar Negara Republik Indonesia Tahun 1945. Undang-Undang Nomor 17 Tahun 2014 tentang Majelis 
Permusyawaratan Rakyat,

Dewan Perwakilan Rakyat,

Dewan Perwakilan Daerah, dan

Dewan Perwakilan Rakyat

Daerah.

Undang-Undang Nomor 13 Tahun 2019 tentang Perubahan Ketiga atas Undang-Undang Nomor 17 Tahun 2014 tentang Majelis Permusyawaratan Rakyat, Dewan Perwakilan Rakyat, Dewan Perwakilan Daerah, dan Dewan Perwakilan Rakyat Daerah. 